\title{
Effects of Feeding Genetically Modified Crops to Domestic Animals: A Review
}

\author{
Muhammad Zeeshan Akram,a, Sema Yaman Fırıncıŏglu, ${ }^{1, b, *}$, Hassan Jalal,c, Sibel Canoğulları Doğan ${ }^{1, d}$, \\ Sana Shahid ${ }^{2, \mathrm{e}}$, Basit Shaukat Ali ${ }^{2, f}$
}
${ }^{1}$ Animal Production and Technologies Department, Faculty of Agricultural Sciences and Technologies, Niğde Ömer Halisdemir University, 51240 Niğde, Turkey
${ }^{2}$ Department of Pathobiology, College of Veterinary and Animal Sciences, University of Veterinary and Animal Sciences sub Campus, Jhang 35200, Pakistan
* Corresponding author

\begin{tabular}{l|l}
$\begin{array}{l}\text { A R T I C L E I N F O } \\
\text { "This study was presented as an oral } \\
\text { presentation at the 4th International } \\
\text { Anatolian Agriculture, Food, } \\
\begin{array}{l}\text { Environment and Biology Congress } \\
\text { Afyonkarahisar, TARGID 2019) }\end{array}\end{array}$ & $\begin{array}{l}\text { Genetically modified (GM) crops are being planted at large scale worldwide. In most of the } \\
\text { countries, GM crops are processed into livestock feed. The land is used for cultivation of GM plants } \\
\text { has been increased in recent years; in } 2012 \text { GM plants were grown on over } 170 \text { million hectares in } \\
28 \text { countries by } 17.3 \text { million farmers and extended to } 185.1 \text { million hectors in } 2016 \text { worldwide. GM } \\
\text { plants have been used as feed for animals and the number of studies has proved their safety for } \\
\text { animal and public health. This paper reviews the possible effects of GM crops on livestock, poultry, } \\
\text { and aquatic animals by reviewing different type of studies, in which parameters such as performance, } \\
\text { reproductive and health assessment were investigated. The most of peer-reviewed papers evaluating } \\
\text { the effects of feeding animals with transgenic crops were based on GM plants with improved } \\
\text { agronomic traits i.e. herbicide-tolerant plants and pets-tolerant plants; however, in some cases GM } \\
\text { plants with boosted nutritional properties assessed. In most experiments, either Bt (Bacillus } \\
\text { thuringiensis) maize, Roundup Ready (RR) soybean or both fed to animals. Measurable differences } \\
\text { in various parameters were mostly observed in Bt maize and soybean fed separately or } \\
\text { Accepted : } 08 / 10 / 2019\end{array}$ \\
$\begin{array}{l}\text { Keywords: } \\
\text { GM-crops } \\
\text { Ruminant } \\
\text { Poultry } \\
\text { Performance } \\
\text { Health }\end{array}$ & $\begin{array}{l}\text { products in the nutrition of domestic animals on performance, health and reproductive parameters } \\
\text { are investigated. }\end{array}$
\end{tabular}

\section{Introduction}

Thousands of years ago, plants with favorable characteristics have been produced with the conventional breeding methods. Traits of desirable characteristics are selected, combined and propagated by sexual crossing method to produce new varieties, but it takes times. New technology has been introduced which not only overcome the hindrance of sexual incompatibility between variable plant species (Southgate et al., 1995) but also used to improve the nutritional contents of plants.

All GM crops are transgenic plants which have been genetically modified by using genetic engineering techniques (generally called Recombinant DNA technology) (Sticklen, 2005; Conard U, 2005; Ma JKC et al., 2003; James, 2011). Nowadays, large amounts of GM crops are being used as feed material in animals (Flachowsky et al., 2012).
The commonly grown transgenic crops are maize, cotton, soybean, rice, and canola (rapeseed) in which a gene has been introduced to plants by transgenesis either for insect resistance or herbicide tolerance (Flachowsky et al., 2012). GM maize is introduced mainly insect-resistant Bt (Bacillus thuringiensis) genes (James, 2011) and GM Roundup Ready (RR) soybeans are incorporated with herbicide tolerance genes (Sieradzki et al., 2006). The main focus of these studies to evaluate the safety of feeding GM crops to animal by considering animal and public health. In Europe, GM crop safety is assessed by the panel on GMO (Genetically Modified Organism) of the European Food Safety Authority (EFSA) based on comparative studies of their molecular, compositional, phenotypic, and agronomic traits and its near-isogenic equivalent crops (EFSA, 2011; EFSA, 2015). Hence, most studies evaluated the feeding GM crops effect on animal health and most on performance 
parameters such as daily weight gain, feed conversion, dry matter intake, and reproduction (Aumaitre, 2004; Flachowsky et al., 2007). The effect of Bt maize and RR soybean on the performance of cattle, pigs, and poultry are most extensively studied in table $1-4$. Bt maize contains the cry $1 \mathrm{Ab}$ gene obtained from the Bacillus thuringiensis which showing resistance to a wide range of Lepidoptera insects. Mammals lack the intestinal receptors for the Cry $1 \mathrm{Ab}$ protein produced by this gene and are not believed to be affected by this toxin (Schnepf et al., 1998).

To date, considerable number of review articles on GM crops and their effects on livestock animals have been published up to 2014. In this article, literature are investigated on effects of feeding GM crops on domestic animals from the period 2014-2019 using the search engines like Scopus, Web of Sciences, Google Scholar and PubMed. Scientific publications reported on the experiments transgenic plants were fed to ruminants, pigs, poultry, or aquatic animals and their effect on health parameters were examined. The observed effects of these GM crops on various parameters in animals are summarized in table 1-4. For this purpose, only studies containing the control groups were selected. In published studies, this review evaluated the performance parameters (average daily weight gain, body weight, and feed conversion), reproductive traits (litter size, birth weight) and health parameters (body condition score, organ weight, hematology, serum biochemistry, histopathology, clinical examination, immune response, and gastrointestinal microbiota).

\section{Effects of Feeding with GM Crops on Ruminants}

Three studies with maize (MON 810) and soybean (Roundup Ready, MON 40-3-2) separately or simultaneously were conducted (Furgal Dierżuk et al., 2014; 2015; Tudisco et al., 2015) in ruminants (Table 1), significant differences between GM crops fed animals and control animals observed by (Tudisco et al., 2015). They evaluated the in vivo and post mortem carcass traits and immunoglobulin $\mathrm{G}$ concentration in kids born from goats fed GM and non-GM soybean. Furthermore, they also investigated the goat colostrum quality, in terms of chemical composition, immunoglobulin concentration, and the presence of feed DNA fragments. Birth weight significantly $(\mathrm{P}<0.05)$ higher in the non-GM fed group while only carcass weights were significantly affected by the treatment resulting in GM soybean-fed group. Colostrum from GM-fed groups showed a significantly lower percentage of protein and fat, either serum or colostrum IgG concentration $(\mathrm{mg} / \mathrm{mL})$. Transgenic DNA sequences were detected in colostrum from the animals receiving GM-soybean meal but not observed in samples from the goats fed with non-GM soybean.

Table 1 Summary of studies testing the effects of GM-crops on ruminants

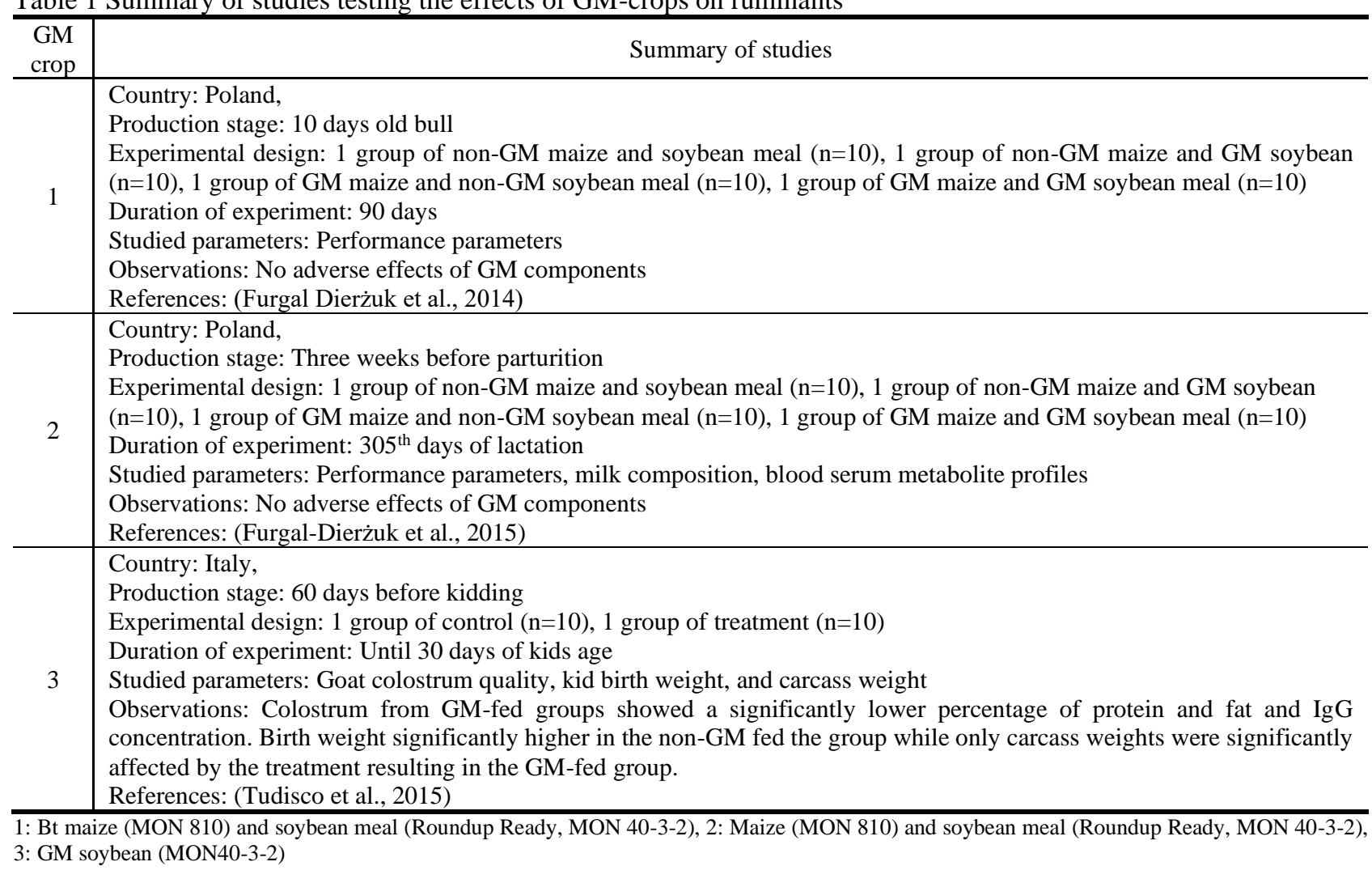

Furgal Dierżuk et al. (2014) performed an experimental study to determine the effects of GM maize (MON 810) and soybean meal (Roundup Ready, MON 40-3-2) on performance parameters, basal chemical composition of the musculus thoracis (MT), fatty acid composition of intramuscular fat, and transfer of transgenic DNA to calf tissues, as well as the histological examination of organs and tissues of Polish Black and White Holstein Frisian calves. In this study, bulls aged 10 days were divided into four groups. The experiment was conducted for 90 days. There were no significant differences between all groups in final live weight, average daily weight gain, MT 
chemical composition and fatty acid profile of intramuscular fat. The calf rumen fluid contained tDNA, but there was no tDNA in the intestinal content, blood, studied organs, or meat. Histological examination of the investigated organs and muscles found no differences among treatments.

Furgal Dierżuk et al. (2015) conducted same study on 40 Polish Holstein-Friesian cows to evaluate the effects of GM maize (MON 810) and soybean meal (Roundup Ready, MON 40-3-2) on performance parameters, milk composition, blood serum metabolite profiles and transfer of tDNA into the milk of cows. This study was conducted from the $3^{\text {rd }}$ week before parturition to the 305th day of lactation. There were no significant differences between transgenic and non-transgenic feeds in productivity, milk composition and blood metabolite profiles such as $\beta$ hydroxybutyric acid, free fatty acids, glucose, insulin, and progesterone. The transgenic DNA sequences of MON 810 and RR soybean meal were not detectable by PCR in milk.

\section{Effects of Feeding with GM Crops on Pigs and Rabbits}

Many kinds of research were conducted to evaluate the safety of GM feeding in pigs and rabbits either by giving Bt rice (Liu et al., 2018a, Liu et al., 2018b, Liu et al., 2017) or Bt maize (Chen et al., 2016, Yalçin et al., 2018) presented in Table 2. Chen et al., (2016) conducted a study to investigate the chronic effect of transgenic maize comprise of Cry $1 \mathrm{Ab}$ protein $(1.64 \mathrm{mg} / \mathrm{kg})$ to evaluate the growth performance, immune response and health of Wuzhishan pig after 196-day GM maize feeding. Longterm feeding Bt corn results had no adverse effects of GM maize on pigs. Later on, Liu et al., (2017) performed an experiment to evaluate the chronic effects of $\mathrm{Bt}$ rice carrying the Cry $1 \mathrm{Ab}$ protein $(1.64 \mathrm{mg} / \mathrm{kg})$ on offspring of highly inbred Wuzhishan pigs. The result showed that only difference occurs in the average daily gain and feed conversion ratio (FCR) of the females in week 3 and males from weeks 1 to 10 were different between both groups and the body weight of the male pigs in week 2 was greater in the non-GM group than that of the $\mathrm{Bt}$ group $(\mathrm{P}<0.05)$. There was no effect on sex steroid level, hematology parameters, relative organ weights, or histopathology. Consequently, long-term intake of transgenic rice had no adverse effects on pig offspring. In addition, Liu et al., (2018b) observed the effects of GM rice containing Cry1 Ab protein $(1.64 \mathrm{mg} / \mathrm{kg})$ on male and female pigs at least for 360 days. The result showed that $\mathrm{Bt}$ rice had no effect on growth indexes, reproductive performances, hematology, and organ- morphology after long-term feeding except that total protein and bilirubin was higher in the non-GM group compared to the Bt group $(\mathrm{P}<0.05)$ but total bilirubin difference did not exist in male pigs (P>0.05).

The effects of GM maize in New Zealand rabbits were evaluated by conducting an experiment to study effects on liver and kidney organ weights, malondialdehyde (MDA) and glutathione (GSH) levels of liver and kidney tissues. In this study, rabbits were divided into three groups: parental, first-generation and second-generation and further divided into subgroup i.e. control group and the treatment group, on which control group was fed with conventional maize (non-GM) and treatment groups were fed with GM maize.
The results indicated an increase in liver weights and decrease in kidney weights observed as generations passed in GM maize-fed group. Significant decrease in GSH and increase in MDA in all three generations fed with GM maize (Yalçin et al., 2018).

\section{Effects of Feeding with GM Crops on Poultry}

In a series of experimental studies, transgenic soybean meal, maize, canola meal, and rice included separately or simultaneously in the diet did not adversely influence the health status, reproduction traits, and cellular immune response of broiler chickens, laying hens and quails (Korwin-Kossakowska et al., 2016; Sartowska et al., 2015; Halle and Flachowsky, 2014; Gao et al., 2014; Zhong et al., 2016; Liu et al., 2016; Lili et al., 2017; McNaughton et al., 2014). All the studies are illustrated in Table $3 \mathrm{a}$ and $3 \mathrm{~b}$.

Czerwinski et al., (2015a), Czerwinski et al., (2015b), Li et al., (2015) and Hameed et al., (2016) also found no negative effect of dietary supplementation of GM maize, rice, soybean meal and sugarcane on hematological, biochemical and histopathological parameters of broilers.

Lili et al. (2017), McNaughton et al. (2014), Halle and Flachowsky (2014) and Sartowska et al. (2015) did not observe any adverse effect of feeding transgenic maize, rice, soybean and canola meal on growth performance parameters, carcass traits, nutrient digestibility and intestinal microbiota of broilers, laying hens and quails.

Kim (2019) conducted a study on two-day-old broilers for 32 days by using GM maize and soybean simultaneously. They evaluated the growth performance, nutrient digestibility, carcass weight and meat quality of broilers. They found that total lysine, methionine, and threonine of non-GM grains were lower than that of GM grains. The protein content of GM soybean meal was higher than that of non-GM soybean meal. Feed intake and FCR were greater $(\mathrm{P}<0.05)$ in broilers provided with nonGM diet than that of the GM group from day 17 to 32 . A decrease in FCR has observed in birds fed the GM diet through the entire experiment $(\mathrm{P}<0.05)$. No significant impacts on blood profile, meat quality, and nutrient digestibility were found in response to dietary treatments.

Papineni et al., (2017) conducted a 42-day broiler study with diets containing toasted DAS-44406-6 soybean meal to evaluate nutritional wholesomeness and safety compared with non-transgenic, near-isoline soybean and non-transgenic references varieties as conventional comparators (Dairyland 99915, Porter 75148, and Williams 82). On measurements, only thigh weight was numerically different between birds fed DAS-44406-6 soybean meal and those fed isoline soybean meal. However, no significant differences to thigh weight were observed between birds fed DAS-44406-6 soybean and any of the non-transgenic reference varieties. Results indicate that DAS-44406-6 soybeans are nutritionally equivalent to conventional varieties.

Czerwiński et al., (2017) checked the effects of GM soybean meal and maize on the diversity and activity of microbiota inhabiting terminal gut segments in broiler chickens. In the ileum and caecum of all groups, members representing the orders Clostridiales, Lactobacillales, and Selenomonadales were present, accompanied by Bifidobacteriales in the caecum. 
Table 2 Summary of studies testing the effects of GM-crops on pigs and rabbits

\begin{tabular}{|c|c|}
\hline $\begin{array}{l}\text { GM } \\
\text { crop }\end{array}$ & Summary of studies \\
\hline 1 & $\begin{array}{l}\text { Country: China, } \\
\text { Production stage: } 3 \text {-month-old pigs } \\
\text { Experimental design: Non-GM (female } N=7 \text {, male } n=7 \text { ), GM rice (female } n=7 \text {, male } n=7 \text { ) } \\
\text { Duration of experiment: } 75 \text { days } \\
\text { Studied parameters: Growth, reproductive performance, hematology, Histopathology organ morphology } \\
\text { Observations: No effects of GM feeding observed } \\
\text { References: (Liu et al., } 2018 \mathrm{a} \text { ) }\end{array}$ \\
\hline 2 & $\begin{array}{l}\text { Country: China, } \\
\text { Production stage: } 3 \text {-month-old pigs } \\
\text { Experimental design: Non-GM (female } \mathrm{n}=6 \text {, male } \mathrm{n}=5 \text { ), Gm-rice (female } \mathrm{n}=11 \text {, male } \mathrm{n}=5 \text { ) } \\
\text { Duration of experiment: } 360 \text { days } \\
\text { Studied parameters: Growth, hematology, organ weights and histopathology } \\
\text { Observations: The average daily gain and feed conversion ratio of the female pigs in week } 3 \text { and the male pigs in weeks } 1 \\
\text { were significantly different }(\mathrm{P}<0.05 \text { ) between the Bt and isogenic groups. } \\
\text { References: (Liu et al., } 2017 \text { ) }\end{array}$ \\
\hline 3 & $\begin{array}{l}\text { Country: China, } \\
\text { Production stage: } 3 \text {-month-old pigs } \\
\text { Experimental design: Non-GM group }(\mathrm{n}=26), \mathrm{GM} \text { group }(\mathrm{n}=27) \\
\text { Duration of experiment: } 360 \text { and } 420 \text { days (Two generations) } \\
\text { Studied parameters: Gut microbiota, histopathology } \\
\text { Observations: No adverse effects of GM feeding observed } \\
\text { References: (Liu et al., } 2018 \mathrm{~b} \text { ) }\end{array}$ \\
\hline 4 & $\begin{array}{l}\text { Country: China, } \\
\text { Production stage: } 40 \text { days old pigs } \\
\text { Experimental design: Isogenic corn-soybean meal-control diet, Bt corn-soybean meal-control diet } \\
\text { Duration of experiment: } 196 \text { days } \\
\text { Studied parameters: Growth, immune response, and health } \\
\text { Observations: No adverse effects of GM feeding observed } \\
\text { References: (Chen et al., 2016) }\end{array}$ \\
\hline 5 & $\begin{array}{l}\text { Country: Turkey, } \\
\text { Production stage: Rabbit } \\
\text { Experimental design: A control group ( } 3 \text { female, } 3 \text { male), GM maize treated group ( } 3 \text { female, } 3 \text { male) } \\
\text { Duration of experiment: parental, first-generation and second-generation } \\
\text { Studied parameters: Liver and kidney organ weights, malondialdehyde (MDA) and glutathione (GSH) levels of liver and } \\
\text { kidney tissues } \\
\text { Observations: Increase in liver weights and decrease in kidney weights observed as generations passed. Significant decrease } \\
\text { in GSH and an increase in MDA in all three generations fed with GM maize. } \\
\text { References: (Yalçin et al., 2018) }\end{array}$ \\
\hline
\end{tabular}

The diversity of the order Lactobacillales in the ileum and caecum of birds fed GM maize was reduced, while that of Lactobacillales in the ileum and Bifidobacteriales in the caecum of birds fed GM soybean was higher compared with conventional maize and soybean. The use of GM and conventional maize and soybean did not affect the activity of microbiota measured as bacterial enzyme activity and the concentration of short-chain fatty acids in the ileal and caecal digesta. The GM maize did not change the resistance of E. coli or Clostridium against antibiotics, while GM soybean slightly increased the resistance of Clostridium from the ileum against kanamycin and those from caecum against kanamycin and erythromycin compared with conventional feedstuffs. In conclusion, the use of GM soybean and maize MON810 in diets did not affect the broiler intestinal ecosystem.

\section{Effects of Feeding with GM Crops on Aquatic Animals}

Data on the effects of GM crops feeding on aquatic animals have mostly concerned Bt maize in which most of the scientific publications observed no adverse influence of GM supplementations except ( $\mathrm{Gu}$ et al., 2014). All the studies are explained in Table 4. They observed that mortality, growth performance and body composition were similar in fish fed the GM and non-GM maize varieties. The Bt maize-fed fish, however, displayed minor but significantly decreased digestive enzyme activities of leucine aminopeptidase and maltase, as well as the decreased concentration of gut bile salts, but significantly increased amylase activity at some sampling points. Histomorphological, radiographic and mRNA expression evaluations did not reveal any biologically relevant effects of $\mathrm{Bt}$ maize in the gastrointestinal tract, liver or skeleton. Cry $1 \mathrm{Ab}$ protein or other compositional differences in GM $\mathrm{Bt}$ maize may cause minor alterations in intestinal responses in juvenile salmon, but without affecting overall survival, growth performance, development or health.

To check the biosafety of transgenic crops in aquatic animals, Zhu et al. (2015) conducted a study to evaluate the effects of Bt rice on frogs. They carried out the study for 90 days with $30 \% \mathrm{Bt}$ rice, $30 \%$ parental rice or no rice as a control. On the assessment of biological, clinical, pathological and growth parameters, non-significant differences were found in body weight, body length, animal behavior, visceral organ weight, liver and kidney function, or the microstructure of some tissues between the froglets fed on the $\mathrm{Bt}$ rice containing diet and those fed on the parental rice or control diets. 
Table 3a Summary of studies testing the effects of GM-crops on poultry

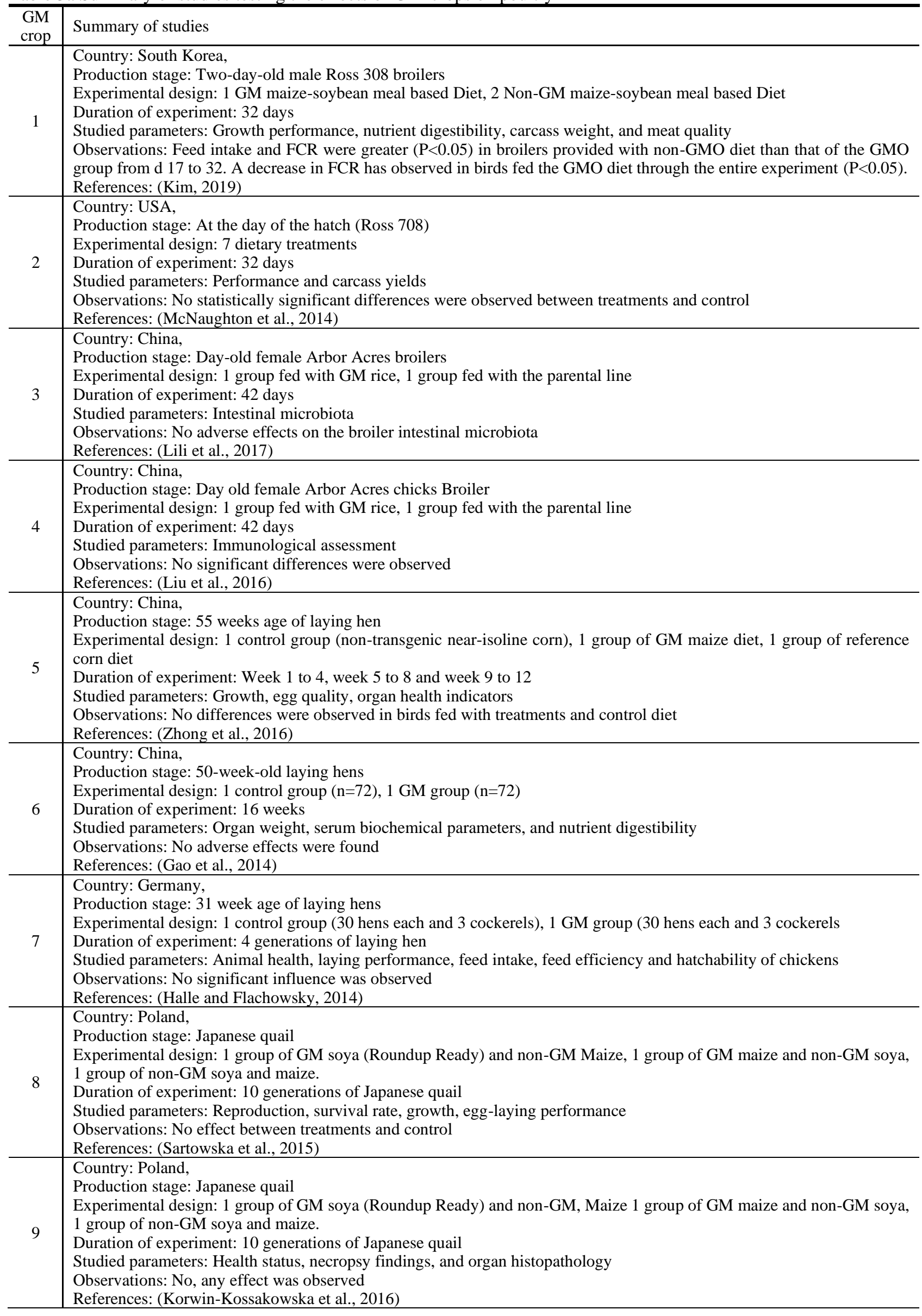


Table 3b Summary of studies testing the effects of GM-crops on poultry

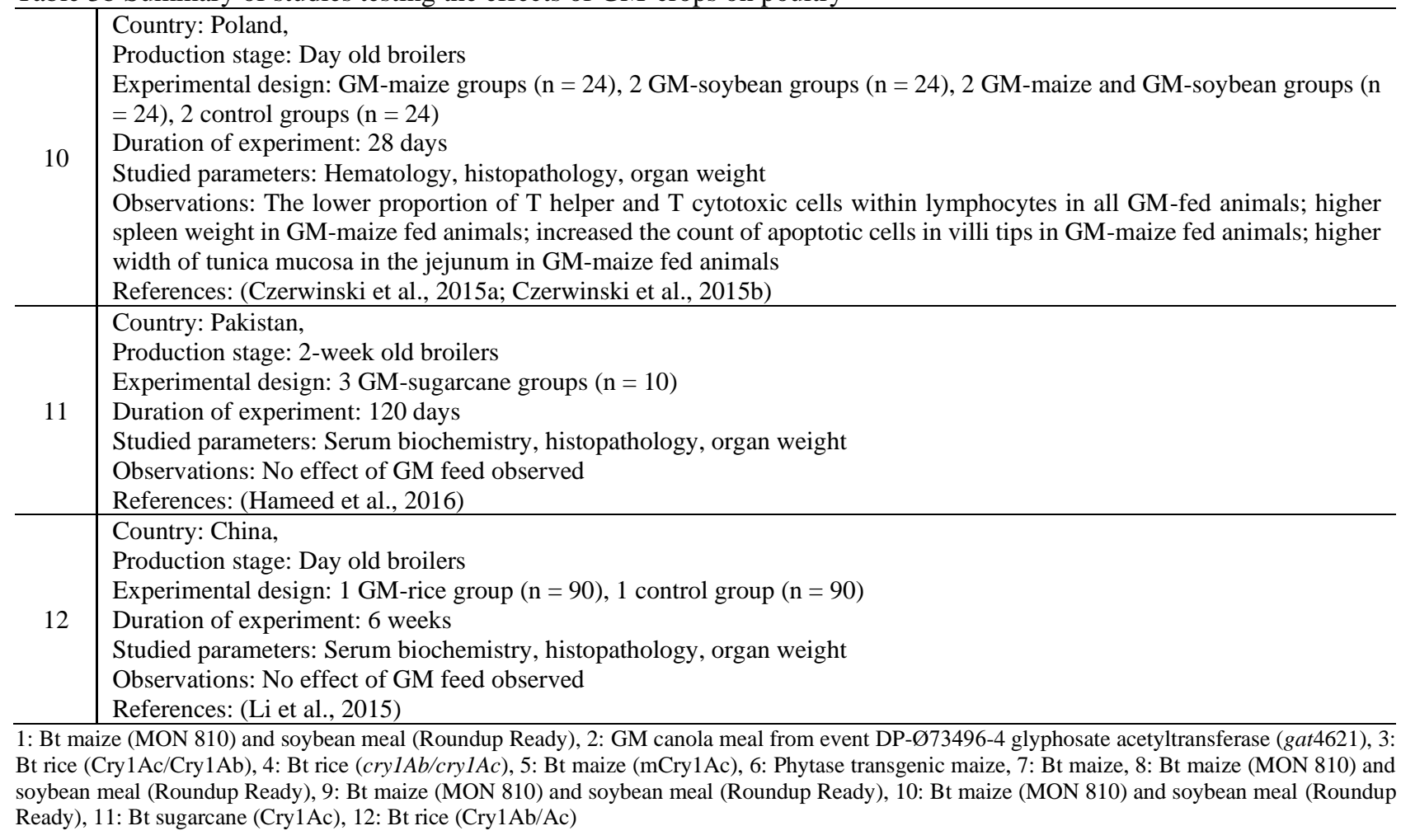

Table 4 Summary of studies testing the effects of GM-crops on aquatic animals

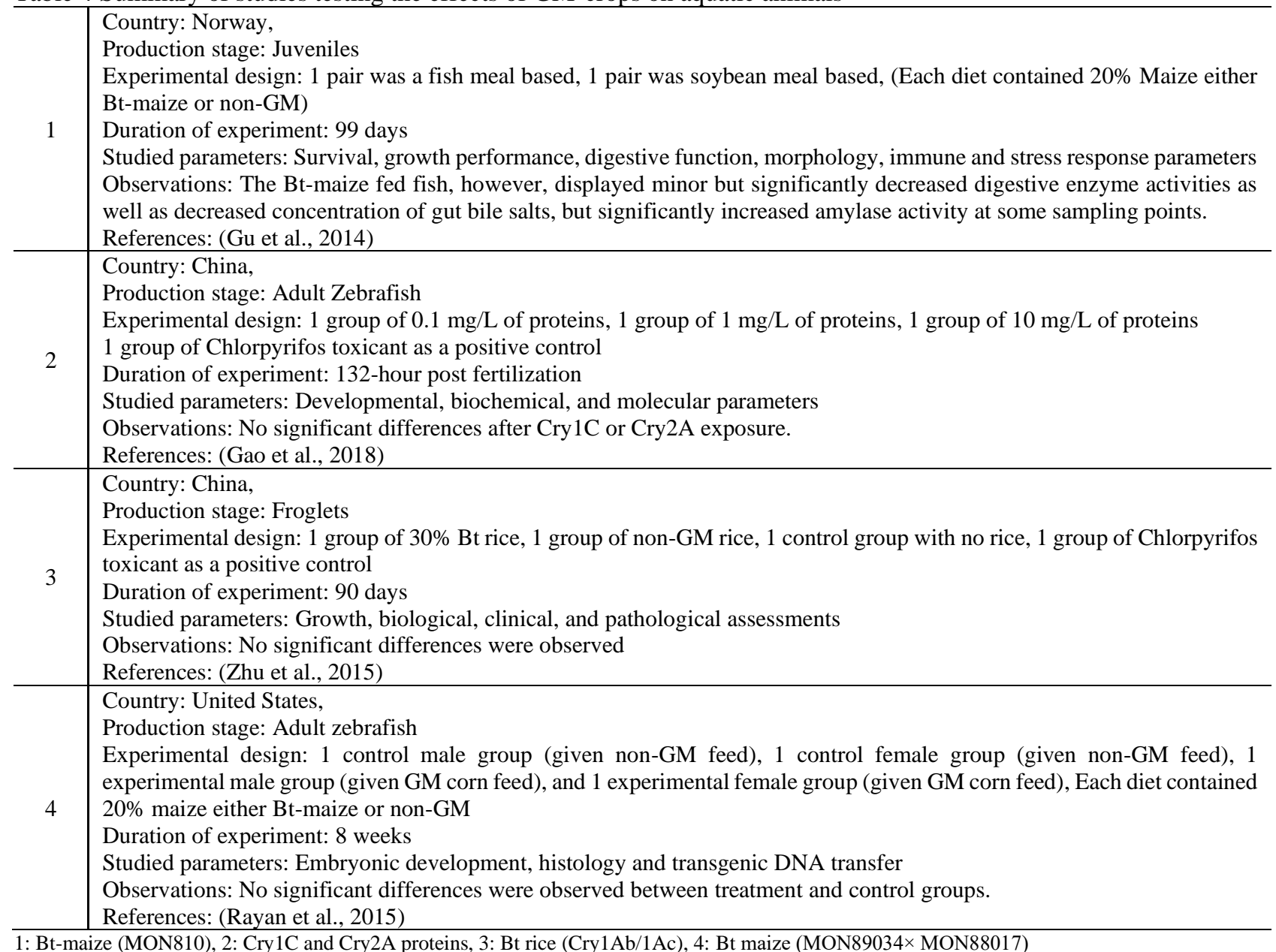

1: Bt-maize (MON810), 2: Cry1C and Cry2A proteins, 3: Bt rice (Cry1Ab/1Ac), 4: Bt maize (MON89034× MON88017) 


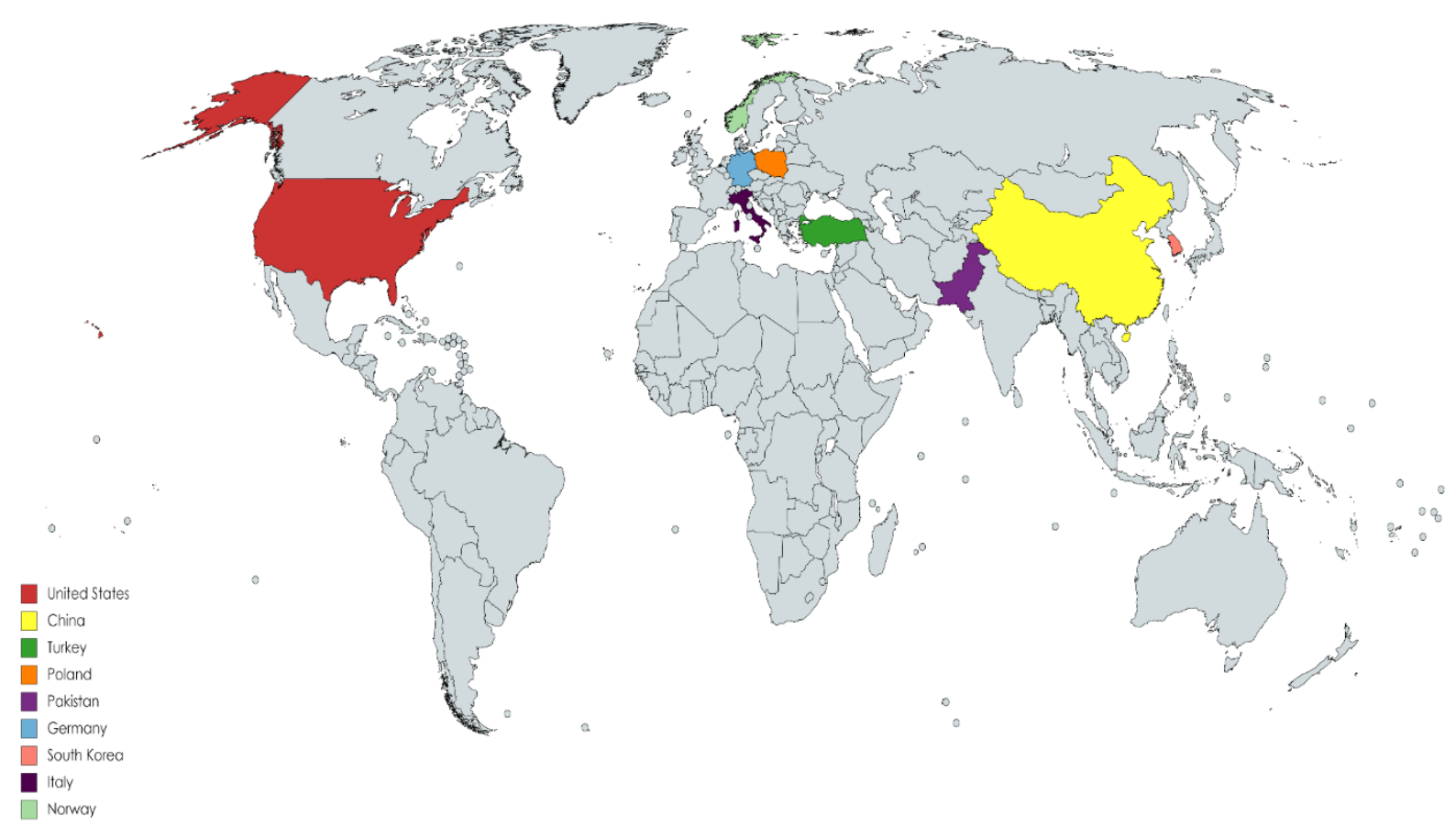

Fig 1 Country where the majority of studies investigated the effects of feeding transgenic crops to animals have been conducted during 2014-2019

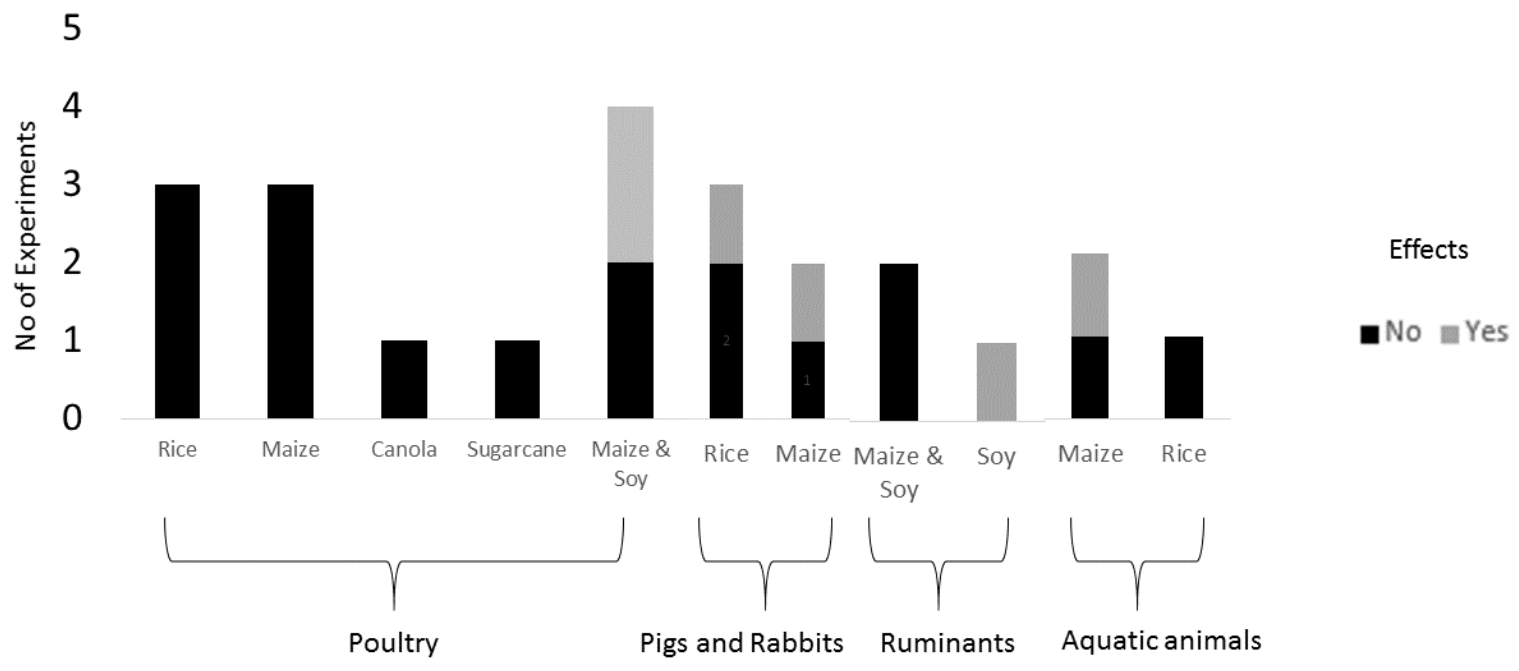

Fig 2 Number of experiments per animal species and GM crop in which various parameters were studied. Black bars indicate the experiments in which no health effects were observed. Grey bars indicate the experiments in which effects were observed (i.e. a significant difference $(\mathrm{P}<0.05)$ between $\mathrm{GM}$-fed animals and control animals for at least one health parameter).

Rayan et al. (2015) assessed the effect of feeding stacked GM corn event $($ MON89034 $\times$ MON88017) on embryonic development, adult tissue histology and assessed the possibility of transgenic DNA transfer, using zebrafish as an animal model. No changes or abnormalities were observed in embryonic morphology nor in any of the tissues examined histologically. In addition, no plant DNA reference genes or transgenic DNA were found in any of the analyzed samples. Results of these studies indicate that the safety and nutrition of GM crops are similar to non-GM crops and growth, health and development were not adversely affected by dietary intake of GM-crops. 


\section{Conclusion}

There are several studies that show different effects of feeding with GM feed sources in different animals. In other relevant studies of feeding GM crops, not only production parameters but also the metabolic status of animals were analyzed and only a few minor treatment differences have been found, with less or no biological relevance for poultry and livestock. The majority of studies investigating the effects of feeding transgenic crops to animals have been conducted in Europe and Asia with most experiments being performed in Poland and China. While few studies were performed in Germany, Norway, Italy, Pakistan, South Korea, and the USA (Fig. 1). Almost half of the experimental studies investigated hematology and histopathology, whereas about a quarter of the studies investigated organ weight, serum biochemistry, and the immune response. The significant differences in health, immune and production parameters between GM-fed animals and control animals were most often observed when GM maize and soybean were fed either separately or simultaneously, especially when fed to poultry (Fig. 2). Despite the presence of international guidelines for feeding trials with GM crops in animals, many published studies undergo from serious weaknesses with respect to experimental design, statistical analysis, and the use of non-GM feed for comparison purposes. The majority of the reviewed studies indeed fed the control animals with the near-isogenic counterpart of the GM crop that was evaluated, although the growing conditions of the crops were not always provided. A well-described protocol must be designed to evaluate the effects of GM feed on animal health particularly to evaluate the health effects of secondgeneration GM crops. In our review, only experiments with first-generation GM crops were included. Health effects of feed based on the second generation GM crops have not been evaluated yet in livestock experiments. For these GM crops feeding studies in target animals are a prerequisite to evaluate their effect on health parameters because their composition is substantially modified and no near-isogenic counterpart may be available. Based on this review, we concluded that there is no clear evidence that GM feed has adverse effects on animal production. The result presented in many studies shows that commercialized transgenic crops can be safely included in feed for animals and it can affect positively on the production as well as on health status of the animals so it could be safe to fed GM crops to livestock, poultry, and aquatic animals.

\section{References}

Aumaitre A. 2004. Safety assessment and feeding value for pigs, poultry and ruminant animals of pest protected $(\mathrm{Bt})$ plants and herbicide tolerant (glyphosate, glufosinate) plants: interpretation of experimental results observed worldwide on GM plants. Italian Journal of Animal Sciences; 3, 107e121.

Chen L, Sun Z, Liu Q, Zhong R, Tan S, Yang X, Zhang H. 2016. Long-term toxicity study on genetically modified corn with cry1Ac gene in a Wuzhishan miniature pig model. Journal of the Science of Food and Agriculture; 96, 4207-4214.

Conard U. 2005. Polymers from plants to develop biodegradable plastics. Trends in Plant Sciences; 10, 511-2.
Czerwinski J, Bogacki M, Jalali BM, Konieczka P, Smulikowska S. 2015a. The use of genetically modified Roundup Ready soyabean meal and genetically modified MON 810 maize in broiler chicken diets. Part 1. Effects on performance and blood lymphocyte subpopulations. Journal of Animam and Feed Sciences; 24, 134e143.

Czerwinski J, Slupecka-Ziemilska M, Wolinski J, Barszcz M, Konieczka P, Smulikowska S. 2015b. The use of genetically modified Roundup Ready soyabean meal and genetically modified MON 810 maize in broiler chicken diets. Part 2. Functional status of the small intestine. Journal of Animal and Feed Sciences; 24, 144e152.

Czerwiński J, Śliżewska K, Korwin-Kossakowska A, Bachanek I, Smulikowska S. 2017. Effects of genetically modified maize and soybean meal on the diversity and activity of gut microbiota in broiler chicken. Animal Science Papers and Reports; 35, 279-299.

EFSA, 2011. Scientific opinion. Guidance for risk assessment of food and feed from genetically modified plants. EFSA panel on Genetically Modified Organisms (GMO). EFSA Journal; $9,2150$.

EFSA, 2015. Scientific opinion. Guidance on the agronomic and phenotypic characterization of genetically modified plants. EFSA Panel on Genetically Modified Organisms (GMO). EFSA Journal; 13, 4128

Flachowsky G, Aulrich K, B€ohme H, Halle I. 2007. Studies on feeds from genetically modified plants (GMP) e Contributions to nutritional and safety assessment. Animal Feed Sciences and Technology; 133, 2e30.

Flachowsky G, Schafft H, Meyer U. 2012. Animal feeding studies for nutritional and safety assessments of feeds from genetically modified plants: a review. Journal für Verbraucherschutz und Lebensmittelsicherheit; 7(3), 179194.

Furgal-Dierżuk I, Strzetelski J, Kwiatek K, Twardowska M, Mazur M, Sieradzki Z, Kozaczyński W, Reichert M. 2014. The effect of genetically modified maize (MON 810) and soyabean meal (Roundup Ready) on rearing performance and transfer of transgenic DNA to calf tissues. Journal of Animal and Feed Sciences; 23, 13-22.

Furgal-Dierżuk I, Strzetelski J, Twardowska M, Kwiatek K, Mazur M. 2015. The effect of genetically modified feeds on productivity, milk composition, serum metabolite profiles and transfer of tDNA into milk of cows. Journal of Animal and Feed Sciences; 663, 127.

Gao C, Ma Q, Zhao L, Zhang J, Ji C. 2014. Effect of dietary phytase transgenic corn on physiological characteristics and the fate of recombinant plant DNA in laying hens. AsianAustralasian Journal of Animal Sciences; 27, 77.

Gao YJ, Zhu HJ, Chen Y, Li YH, Peng YF, Chen XP. 2018. Safety assessment of Bacillus thuringiensis insecticidal proteins Cry $1 \mathrm{C}$ and Cry2A with a zebrafish embryotoxicity test. Journal of Agricultural and Food Chemistry; 66, 43364344.

Gu J, Bakke AM, Valen EC, Lein I, Krogdahl Å. 2014. Bt-maize (MON810) and non-GM soybean meal in diets for Atlantic salmon (Salmo salar L.) juveniles-impact on survival, growth performance, development, digestive function, and transcriptional expression of intestinal immune and stress responses. PloS One; 9, e99932.

Halle I, Flachowsky G. 2014. with genetically modified (Bt) maize in laying hens. Journal of Animal and Feed Sciences; 23, 58-63.

Hameed A, Nasir IA, Tabassum B, Qamar Z, Zameer M, Younus M, Rao AQ, Rashid B, Tariq M, Khan GA, Ali M, Anjum MS, Ahmed A, Bhatti JA, Samiullah TR, Husnain T. 2016. Biosafety assessment of locally developed transgenic sugarcane. Journal of Animal and Plant Sciences; 26, 11241132. 
James C. 2011. Global status of commercialized biotech/GM crops. Ithaca, New York: ISAAA. Vol. 44.

Kim IH. 2019. Non-GMO and GMO (maize-soybean) diet effects on growth performance, nutrient digestibility, carcass weight and meat quality of broiler chicken. Asian-Australasian Journal of Animal Sciences; 32, 849-855

Korwin-Kossakowska A, Sartowska K, Tomczyk G, Prusak B, Sender G. 2016. Health status and potential uptake of transgenic DNA by Japanese quail fed diets containing genetically modified plant ingredients over 10 generations. British Poultry Science; 57, 415-423.

Li Z, Gao Y, Zhang M, Feng J, Xiong Y. 2015. Effects of a diet containing genetically modified rice expressing the Cry $1 \mathrm{Ab} / 1 \mathrm{Ac}$ protein (Bacillus thuringiensis toxin) on broiler chickens. Achieves of Animal Nutrition; 69, 487-498.

Lili G, Deng X, Minhong Z, Changlong S, Jinghai F, Fuping S, Fan L, Jie Z. 2017. High-throughput Sequencing-based Analysis of the Intestinal Microbiota of Broiler Chickens Fed Genetically Modified Rice Expressing Cry1Ac/Cry1Ab Chimeric Bacillus thuringiensis Protein. The Journal of Poultry Science; 0170029.

Liu R, Zhao G, Zheng M, Jie Liu, Zhang J, Peng Li, Li Q, Feng J, Zhang M, Jie WEN. 2016. Effect of feeding transgenic cry $1 \mathrm{Ab} / \mathrm{cry} 1 \mathrm{Ac}$ rice on indices of immune function in broilers. Journal of Integrative Agriculture; 15, 1355-1363.

Liu, Q, Wu S, Li M, Yang W, Wang Y, Wu Y, Gao H, Han Y, Feng S, Zeng S. 2018a. Effects of long-term feeding with genetically modified $\mathrm{Bt}$ rice on the growth and reproductive performance in highly inbred Wuzhishan pigs. Food Control; 90, 382-391.

Liu, Q, Yang W, Li M, Wang Y, Zhang H, Wu Y, Gao H, Han Y, $\mathrm{Bu}$ X, Zeng S. 2018b. Effects of Transgenic Bt Rice Containing the Cry1 Ab Protein on the Gastrointestinal Health of Highly Inbred Wuzhishan Pigs after Two Generations of Feeding. Journal of Agricultural and Food Chemistry; 66, 10575-10587.

Liu, Q, Yang W, Li M, Wu Y, Wang Y, Wu S, Gao H, Han Y, Yang F, Feng S. 2017. Effects of 60-week feeding diet containing Bt rice expressing the $\mathrm{Cry} 1 \mathrm{Ab}$ protein on the offspring of Inbred Wuzhishan pigs fed the same diet. Journal of Agricultural and Food Chemistry; 65, 10300-10309.

Ma JKC, Drake PMW, Christou P. 2003. The production of recombinant pharamaceticals proteins in plants. Nature; 4 , 794-805.

McNaughton J, Roberts M, Rice D, Smith B, Hong B, Delaney B, Iiams C. 2014. Comparison of broiler performance and carcass yields when fed diets containing genetically modified canola meal from event DP-Ø73496-4, near-isogenic canola meal, or commercial canola meals. Poultry Science; 93, 1713-1723.
Papineni S, Fletcher DW, Cromwell GL, Ekmay RD. 2017. Comparative performance of broilers fed diets containing DAS-44406-6 and non-transgenic soybean meal. Poultry Science; 96, 1244-1249.

Rayan AM, Nigussie F, Abbott LC. 2015. Safety Evaluation of Stacked Genetically Modified Corn Event (MON89034× MON88017) Using Zebrafish as an Animal Model. Food and Nutrition Sciences; 6, 285.

Sartowska KE, Korwin-Kossakowska A, Sender G. 2015. Genetically modified crops in a 10-generation feeding trial on Japanese quails-Evaluation of its influence on birds' performance and body composition. Poultry Science; 94, 2909-2916.

Schnepf E, Crickmore N, Van Rie J, Lereclus D, Baum J, Feitelson J, Zeigler DR, Dean DH. 1998. Bacillus thuringiensis and its pesticidal crystal proteins. Microbiology and Molecular Biology Reviews; 62, 775e806.

Sieradzki Z, Walczak M, Kwiatek K. 2006. Occurrence of genetically modified maize and soybean in animal feedingstuffs. Bulletin of the Veterinary Institute in Pulawy; $52,567-570$.

Southgate EM, Davey MR, Power JB, Merchant R. 1995. Factor Affecting the Genetic Engineering of plants by Micro projectile Bombardment. Biotechnology Advances; 13, 63157.

Sticklen M. 2005. Plant genetic engineering to improve biomass characteristics for biofuels. Current Opinion in Biotechnology; 17, 315-9.

Tudisco R, Calabrò S, Cutrignelli MI, Moniello G, Grossi M, Mastellone V, Lombardi P, Pero ME, Infascelli F. 2015. Genetically modified soybean in a goat diet: Influence on kid performance. Small Ruminant Research; 126, 67-74.

Yalçin E, Acar A, Seven B, Taşli B, Çavuşoğlu K. 2018. Effects of feeding genetically modified (GM) maize on oxidative stress parameters in New Zealand rabbit. Global Nest Journal; 20, 173-176.

Zhong RQ, Chen L, Gao LX, Zhang LL, Yao B, Yang XG, Zhang HF. 2016. Effects of feeding transgenic corn with mCry1Ac or maroACC gene to laying hens for 12 weeks on growth, egg quality and organ health. Animal; 10, 1280-1287.

Zhu HJ, Chen Y, Li YH, Wang JM, Ding JT, Chen XP, Peng YF. 2015. A 90 day safety assessment of genetically modified rice expressing Cry $1 \mathrm{Ab} / 1 \mathrm{Ac}$ protein using an aquatic animal model. Journal of Agricultural and Food Chemistry; 63, 3627-3633. 